DOI: http://dx.doi.org/10.1590/S0104-64972015002309

\title{
Population biology of the 'uçá'-crab, Ucides cordatus (Linnaeus, 1763) (Brachyura: Ucididae), in mangroves of the Joanes River, Bahia State, Brazil
}

Elienai Elisia Bastos Moraes, Barbara Janaina Bezerra Nunesmaia and Marcelo Antonio Amaro Pinheiro*

(EEBM) Universidade Católica do Salvador (UCSAL), Campus Pituaçu, Núcleo Integrado de Estudos em Zoologia (NIEZ). Av. Prof. Pinto de Aguiar, 2589, Pituaçu. 41740-090 Salvador, Bahia, Brazil. E-mail: elienaibiocrab@gmail.com

(BJBN) Universidade Federal da Bahia (UFBA), Campus Ondina, Laboratório do Programa de Monitoramento, Avaliação e Reabilitação de Ecossistemas Naturais e Artificiais do Estado da Bahia (MARENBA). Rua Barão de Geremoabo, s/non, Ondina. 40170-115 Salvador, Bahia, Brazil. E-mail: barbarajbn@gmail.com

(MAAP) Universidade Estadual Paulista (UNESP), Campus Experimental do Litoral Paulista (CLP), Laboratório de Biologia de Crustáceos, Grupo de Pesquisa em Biologia de Crustáceos (CRUSTA). Praça Infante D. Henrique, s/nº, Parque Bitaru. 11330-900 São Vicente, São Paulo, Brazil. E-mail: pinheiro@ clp.unesp.br. * Corresponding author

\begin{abstract}
This study evaluated the population structure, relative growth and morphological maturity size in Ucides cordatus in the Joanes River, Bahia State (Brazil). Crabs were sampled in a fragmented and human-altered mangrove ecosystem in a Brazilian Environmental Protected Area (EPA). A total of 431 crabs were sampled (265 males and 166 females) between September 2011 and August 2012. The following measurements were taken using precision callipers: carapace width $(\mathrm{CW})$ and length $(\mathrm{CL})$, the length of the propodus of the major cheliped (PL, males only), and the width of the $5^{\text {th }}$ somite of the abdomen (AW, females only). Specimens were also weighed to a precision of $0.5 \mathrm{~g}$ on a scale to obtain the total wet weight (WW). The relative growth of this species was studied by using biometric relationships to estimate the morphological maturity size in both sexes (PLxCW in males and $\mathrm{AWxCW}$ in females). The overall sex ratio was 1.6:1, with a predominance of males $(p<0.05)$. The population structure of 'uçá'-crabs was composed of two normal curves (juveniles and adults) in both sexes. A relative growth analysis using the CLxCW relationship revealed a negative allometric growth in adult males whereas adult females exhibited an isometric growth, with an inverse pattern occurring in juveniles. In males, the PLxCW relationship indicated a change in allometric growth at $39.4 \mathrm{~mm}$ CW (isometric growth in juveniles changing to positive allometry growth in adults). In females, the AWxCW relationship indicates that morphological maturity occurs at a delay (44.5 $\mathrm{mm} \mathrm{CW}$ ) and that growth changes between phases (positive allometry to isometry). Isometric growth was found using the $\mathrm{WWxCW}$ relationship, also regardless of sex. A literature review combined with results previously published about this species in northeast Brazilian region suggests that $U$. cordatus had a seasonal reproduction during six months (from December to May), with a fattening season in the following six months (June to November). Joanes River is an environmental protected area, but had a high anthropic pressure by closed condos and marinas. Despite the high anthropic pressure on this EPA, the population structure and reproduction of $U$. cordatus did not appear to be affected.
\end{abstract}

Key words: Estuary, Growth, Mangrove land crab, Maturity, Reproduction. 


\section{INTRODUCTION}

Mangroves are important natural ecosystems that promote shoreline stability (Moura and Querino, 2010), retain contaminants in sediments and vegetation (Bernini et al., 2006; Pinheiro et al., 2012), serve as a nursery for several animal species (Adams et al., 2006; Tse et al., 2008), and are indicators of regional/global climatic change (Lima and Oliveira, 2011), in addition to other functions. Nevertheless, Brazilian mangrove ecosystems have been negatively influenced by many anthropic changes, primarily urban expansion (Sobrinho and Andrade, 2009), vegetal suppression and loss of endemic animals (Moreau et al., 2010).

Crustaceans are important faunal components in the mangrove ecosystem (Nicolau and Oshiro, 2007). Among crustaceans, the 'uçá-crab - Ucides cordatus (Linnaeus, 1763) - is part of the family Ucididae according Števčić (2005) and Ng et al. (2008). This species occupies a particularly important position because of its continuous geographic distribution (Amapá to Santa Catarina in Brazil, according to Castro et al., 2008). This ucidid crab lives exclusively in tropical and subtropical mangrove ecosystems, where it builds burrows in the sediment (Hattori and Pinheiro, 2003) and uses the leaves and propagules of mangrove trees as its source of food (Christofoletti et al., 2013). This crustacean is a central component of the benthic mangrove macrofauna (Alves and Nishida, 2004) and a vital fishery resource to artisanal fishermen (Rodrigues et al., 2000). Ucides cordatus was previously classified as overexploited or threatened by exploitation (Ibama, 2004), but its conservation category was recently reviewed and changed to a lower threatened status (NT - near threatened, according MMA, 2014).

Relative growth studies provide the opportunity to estimate the size at morphological maturity for brachyuran crustaceans, making it possible to better understand their adaptive strategies, such as the differential growth of chelipeds and abdomens between the sexes (Masunari and Swiech-Ayoub, 2003; Lima and Oshiro, 2006; Castiglioni and Coelho, 2011). Biometric evaluations can also be extremely valuable tools with which to detect possible anthropic impacts in the environment (Araújo et al., 2012). Other population parameters (e.g., structural composition, longevity, growth/ mortality rates, sex ratio, etc.) can also be quantified and used to explain possible deviations (Wunderlich and Pinheiro, 2013). The size at sexual maturity, for example, is an important population parameter in fishery management and is commonly used by Brazilian lawmakers to promote the sustainable use of 'uçá-crabs (i.e., by mandating a minimum capture size) (Ibama, 2003a; 2003b) and its sustainable management (Ibama, 2011). The size at sexual maturity for $U$. cordatus has been defined by fishery regulations as $60 \mathrm{~mm} \mathrm{CW}$, with little variation among Brazilian regions (Dalabona and Silva, 2005) despite the known effect of latitude on size at sexual maturity (Leite et al., 2009; Castiglioni et al., 2011; Castiglioni and Coelho, 2011). Nevertheless, there are not studies about anthropic changes and their effects on maturity size of $U$. cordatus.

The reproductive season of pleocyemate crustaceans is determined by the months during which females are ovigerous and/or possess mature gonads (Alves, 1975; Sastry, 1983). According to this definition, Pinheiro and Fransozo (2002) report that 'uçá-crabs have a seasonal reproductive pattern, as reproduction only occurs during a few months of the year. The non-reproductive months are considered to be the 'fattening' season (Souto, 2008).

Population structure, biometry and size at morphologic maturity of $U$. cordatus were examined for the first time in the mangroves of the Joanes River estuary, in South Bahia (Brazil), constituting a pioneer study in this Brazilian Environmental Protected Area (EPA).

\section{Material AND Methods}

\section{Study area}

The Joanes River is an important estuary in the state of Bahia (Fig. 1) and provides water to many municipalities in the north littoral of the state. This area is an important tourist destination, but it suffers from the urban expansion of the metropolitan region of Salvador, the capital of this Brazilian state (Reis-Filho et al., 2010). This area is part of the Environmental Protected Area (EPA) of Joanes-Ipitanga (1253'32”S 38 24'09”W) and consists of mangrove fragments surrounded by marinas and closed condominiums. According to Köppen's climate classification (Alvares et al., 2013), this Brazilian region is a tropical zone without a dry season (Af). April and May are the wettest months, and there is an average annual precipitation $>1,600 \mathrm{~mm}$ and an average temperature of $25.4^{\circ} \mathrm{C}$ (Barboza et al., 2006). 


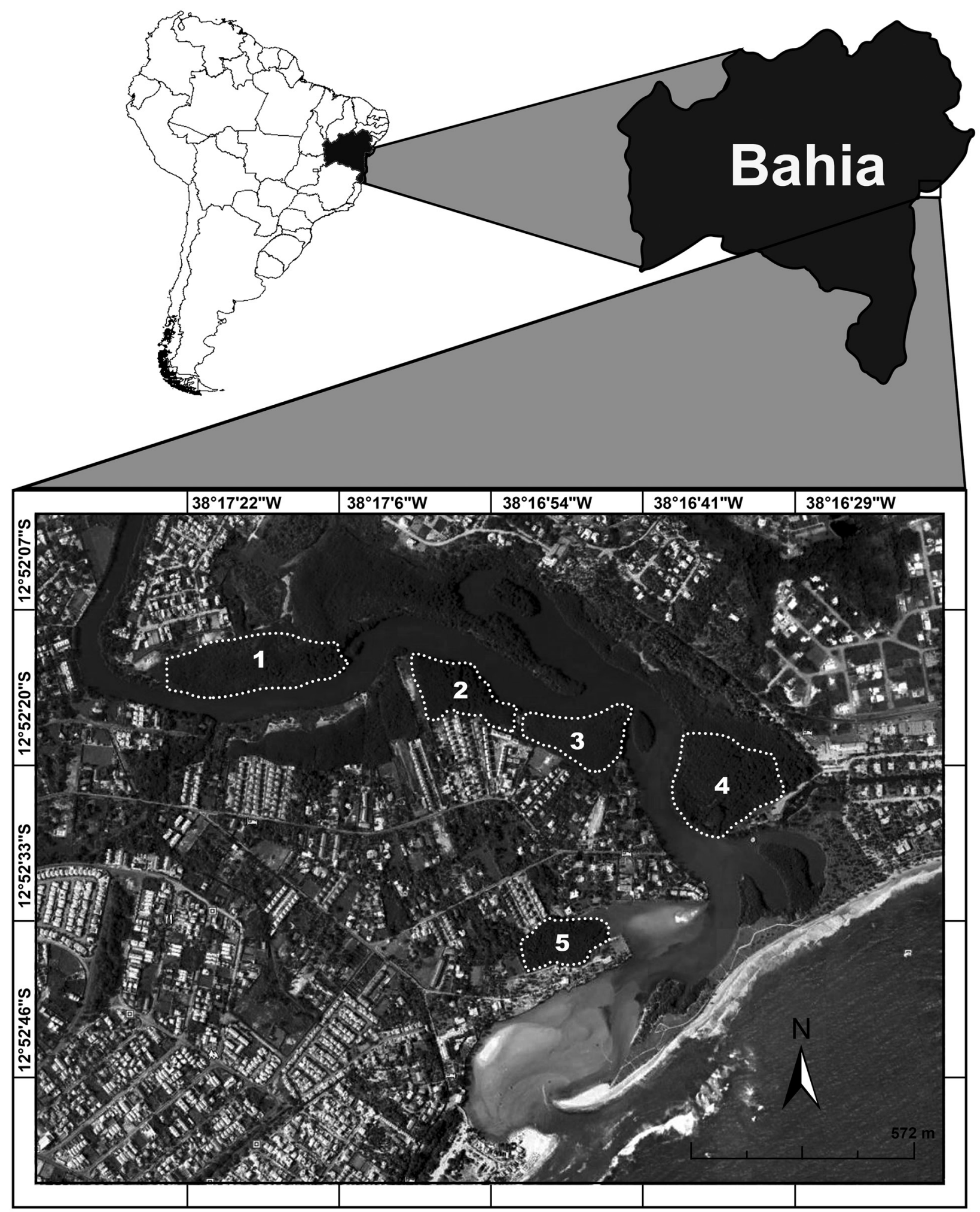

Figure 1. Estuary of the Joanes River, Lauro de Freitas municipality (Bahia State, Brazil), indicating the five mangrove areas where 'uçá'crabs (Ucides cordatus) was captured monthly from September 2011 to August 2012. This satellite photo was modified based on Image (C) 2013 Digital Globe and Image (c) 2013 Terra Metrics, available at Google Earth ${ }^{\mathrm{TM}} 2013$.

Five mangrove areas were demarcated in Joanes River (Fig. 1). These areas were fragmented and altered by human action (e.g., closed condos and marinas), occurring inside of the JoanesIpitanga EPA and randomly selected to better representation of the population analysis. The size 
and arboreal composition was determined for each area by polygon delimitation of a satellite photo obtained from Google Earth ${ }^{\mathrm{TM}}$. The size and arboreal composition for each area is as follows: Area $1\left(52,656 \mathrm{~m}^{2}\right)$ and Area $2\left(31,342 \mathrm{~m}^{2}\right)$ both contained a fringe of Rhizophora mangle around an interior of Laguncularia racemosa, Area 3 (30,435 $\mathrm{m}^{2}$ ) contained only $R$. mangle, Area 4 (56,886 $\mathrm{m}^{2}$ ) contained a fringe of $L$. racemosa surrounding an interior of Avicennia schaueriana, and Area $5\left(21,994 \mathrm{~m}^{2}\right)$ predominately contained $A$. schaueriana. These five mangrove areas contained a total area of $193,313 \mathrm{~m}^{2}$ and had a mangrove canopy height between 4 and $5 \mathrm{~m}$.

\section{Sampling procedures}

In each of five study areas, Ucides cordatus were captured monthly by local crab-catchers for one year (September 2011 to August 2012), except for two months (December and January) during which artisanal fisherman were unavailable because of a regional holiday. Crabs were captured by hand (a capture method called 'braceamento' by Pinheiro and Fiscarelli, 2001 and Vasques et al., 2011), with an effort of one fisherman per hour. Each crab was sexed according to Pinheiro and Fiscarelli (2001), those with ovigerous condition were registered, and specimens were submitted to biometry during field collection using a vernier caliper $(0.01 \mathrm{~mm})$ and a portable precision scale $(0.5 \mathrm{~g})$. The following morphometric variables were registered: carapace width $(\mathrm{CW})$ and length (CL); propodus length of the greater cheliped (PL, males only); abdominal width of the $5^{\text {th }}$ somite (AW, females only); and wet weight (WW). After these data have been obtained, crabs were released in the same mangrove area from which they were captured, avoiding some effect on population or the environment (Cetrel, 2011).

\section{Data categorization and statistical analysis}

Crabs were categorized into three groups (males, females without eggs, and ovigerous females). The absolute abundance (number of individuals) in each category was established for each month, except for December and January due to sampling difficulties. Registries were obtained monthly during the study and clustered according two biological periods (reproductive: January to May; and non-reproductive: June to December). These biological periods were following results previously reported by Araújo and Calado (2008) to Alagoas state, but valid to all northeast Brazilian region (see review by Ibama, 2011). The sex ratio was also calculated for each biological period, and the sexual proportion was compared using the chisquare test (Sokal and Rohlf, 2003).

AShapiro-Wilk (SW) normality test was applied to each biometric variable by sex. If normality was confirmed, the means were compared using Student's t-test; otherwise, a Kruskal-Wallis test was used (Sokal and Rohlf, 2003). Next, the population structure was determined for each sex using the frequency distribution of size classes (CW) to build histograms. Data were subjected to the Bhattacharya method using the NormSep routine in FiSAT software (Gayanilo et al., 1996) to determine the normality of the data components (mean \pm standard deviation) that were compared between sexes.

Relative growth in $U$. cordatus was evaluated based on four biometric relationships, CLxCW, PLxCW, AWxCW, and WWxCW, where CW was the independent variable. Biometric relationships were fitted using power functions $\left(y=a x^{b}\right)$, where $a$ corresponded to the $y$-axis intercept, and $b$ was the relative growth constant (isometry, $b=1$; negative allometry, $b<1$; and positive allometry, $b>1$; according to Huxley, 1950 and Hartnoll, 1982). The same equation was used in the WWxCW relationship, but in this case WW was a cubic variable and $b$ was a function of 3 (e.g., isometry, $b=$ 3 ; negative allometry, $b<3$; and positive allometry, $b>3)$. Male (PLxCW) and female (AWxCW) relationships were analyzed using the "segmented" package in $R, V .2 .5 .0$ (Ihaka and Gentleman, 1996). This mathematical method is similar to that applied by Legendre and Legendre (1998) and estimates the body size $(\mathrm{CW})$ when a growth change has occurred during ontogeny. According to these authors, body size is related to the timing of the onset of morphological maturity in each sex. This relationship was statistically confirmed by using $b$-values between phase lines (juvenile and adult) with the same biometric relationship. The equations obtained for these relationships were classified by $t$-tests and compared with the relative growth equations previously obtained by Pinheiro and Hattori (2006) and with the WWxCW relationship previously obtained by Pinheiro and Fiscarelli (2009). All statistical procedures were evaluated with a significance level of $5 \%$. 


\section{RESUlts}

A total of 431 Ucides cordatus crabs $(265$ males, 141 not-ovigerous females, and 25 ovigerous females) were collected (Tab. 1). The overall sex ratio (male:female) was 1.6:1 $\left(\mathrm{X}^{2}=22.74 ; P<\right.$ 0.01 ). Males were predominant upon females in both biological periods - reproductive $\left(2.1: 1 ; \mathrm{X}^{2}=\right.$ $16.7 ; P<0.01)$ and non-reproductive $\left(1.4: 1 ; \mathrm{X}^{2}=\right.$ $8.88 ; P<0.01)$ - despite the greater abundance of males during non-reproductive period.

Except for PL (measured only in males) and AW (only in female crabs), the sizes of the other biometric variables were higher in males than in females $(P<0.05)$ (Tab. 2). This finding was verified for both measures of $U$. cordatus (CW and $\mathrm{CL}$ ) and total wet weight (WW) (Tab. 3). A comparison among the size (i.e., $\mathrm{CW}$ ) distribution histograms reveals similar amplitude of variation $(25 \mathrm{~mm})$ between sexes, but a greater maximum size in males $(70 \mathrm{~mm})$ than in females $(55 \mathrm{~mm})$. Males and females have average sizes from 55 to $60 \mathrm{~mm}$ and 45 to $50 \mathrm{~mm} \mathrm{CW}$, respectively (Fig. 2). Ovigerous females were found during only three months (March to May), and the greatest frequency of ovigerous females was found in May (Tab. 1; Fig. 3).
The biometric relationships of PLxCW (males), $\mathrm{AWxCW}$ (females) and CLxCW (both sexes) could be represented by two separate equations (juvenile and adults, $P<0.05$ ); the same was not true for the WWxCW relationship $(P>0.05)$ (see Tab. 3). The CLxCW relationship of juvenile males indicated isometric growth $(b=0.94 ; P>$ $0.05)$, which changed to a negative allometry in adults $(b=0.86 ; P<0.05)$ (Tab. 3). The intercept between these equations occurred at $53.7 \mathrm{~mm} \mathrm{CW}$. An inverse growth pattern occurred in females, where the $b$ value changed from $0.91(P<0.05)$ to $1.09(P>0.05)$, with an intercept at $58.0 \mathrm{~mm}$ CW (Tab. III). The PLxCW relationship revealed an isometric growth in juvenile males $(b=1.12 ; P$ $>0.05)$ and allometric positive growth in adults $(b$ $=1.39 ; P<0.05)$, with an intercept at $39.4 \mathrm{~mm}$ $\mathrm{CW}$ (i.e., the size at the onset of morphological maturity in males) (Tab. 3; Fig. 4). In females, a statistically significant morphological change was revealed by the $\mathrm{AWxCW}$ relationship (positive allometry in juveniles and isometry in adults), and both equations had intercepts at $44.5 \mathrm{~mm} \mathrm{CW}$ (i.e., the size at onset of morphological maturity in females) (Tab. 3; Fig. 5). The WWxCW relationship suggests isometric growth in both sexes, represented by only one equation for each sex (Tab. 3).

Table 1. Ucides cordatus (Linnaeus, 1763). The absolute abundance (number of individuals) by sex and population groups in the mangrove areas of the Joanes River, Lauro de Freitas municipality (Bahia State, Brazil), captured monthly between September 2011 and August 2012, with respect to the biological period (reproductive: December to May; non-reproductive: June to November). NO indicates females without eggs, OV indicates ovigerous females, TF indicates total number of females, TG indicates total number of crabs (males + females), and OF\% indicates the percentage of ovigerous females of all total females.

\begin{tabular}{|c|c|c|c|c|c|c|}
\hline \multirow{2}{*}{ Month/Year } & \multirow{2}{*}{ Males } & \multicolumn{3}{|c|}{ Females } & \multirow[t]{2}{*}{ TG } & \multirow[t]{2}{*}{ OF $\%$} \\
\hline & & NO & OV & $\mathrm{TF}$ & & \\
\hline September/2011 & 16 & 9 & 0 & 9 & 25 & 0 \\
\hline October & 29 & 7 & 0 & 7 & 36 & 0 \\
\hline November * & 19 & 2 & 0 & 2 & 21 & 0 \\
\hline December * & - & - & - & - & - & - \\
\hline January/2012 & - & - & - & - & - & - \\
\hline February & 14 & 3 & 0 & 3 & 17 & 0 \\
\hline March & 55 & 12 & 7 & 19 & 74 & 36.8 \\
\hline April & 21 & 3 & 2 & 5 & 26 & 40.0 \\
\hline May & 3 & 2 & 16 & 18 & 21 & 88.9 \\
\hline June & 26 & 19 & 0 & 19 & 45 & 0 \\
\hline July & 69 & 75 & 0 & 75 & 144 & 0 \\
\hline August & 13 & 9 & 0 & 9 & 22 & 0 \\
\hline Total & 265 & 141 & 25 & 166 & 431 & 15.1 \\
\hline Reproductive period & 93 & 20 & 25 & 45 & 138 & 55.6 \\
\hline Non-reproductive period & 172 & 121 & 0 & 121 & 293 & 0 \\
\hline
\end{tabular}

* In these months, crab-catchers were not available to assist in field expeditions. 
Table 2. Ucides cordatus (Linnaeus, 1763). Biometric variables, including the cephalothorax (CW, width; CC, length), the length of the propodus of the major cheliped (PL, for males only), the width of the $5^{\text {th }}$ somite of the abdomen (AW, for females only) and the wet weight (WW), based on the individuals captured monthly in mangroves of the Joanes River, Lauro de Freitas Municipality (Bahia State, Brazil) between September 2011 and August 2012. An n indicates the number of specimens measured and weighed, Min is the minimum value, Max is the maximum value, $\mathrm{x}$ is the mean, and $\mathrm{s}$ is the standard deviation.

\begin{tabular}{lcccccccc}
\hline Biometric & \multicolumn{3}{c}{ Males } & \multicolumn{3}{c}{ Females } \\
\hline Variables & $\mathrm{n}$ & Min & Max & $\mathrm{x} \pm \mathrm{s}$ & $\mathrm{n}$ & $\mathrm{Min}$ & $\mathrm{Max}$ & $\mathrm{x} \pm \mathrm{s}$ \\
\hline CL $(\mathrm{mm})$ & 257 & 20.2 & 50.0 & $39.1 \pm 8.1 \mathrm{~b}$ & 162 & 18.5 & 49.0 & $34.2 \pm 6.6 \mathrm{~b}$ \\
CW $(\mathrm{mm})$ & 261 & 25.0 & 75.0 & $52.4 \pm 11.5 \mathrm{~b}$ & 165 & 21.1 & 65.0 & $44.5 \pm 9.1 \mathrm{a}$ \\
AW (mm) & - & - & - & - & 157 & 8.1 & 39.0 & $26.3 \pm 6.3$ \\
PL (mm) & 145 & 18.4 & 77.0 & $44.3 \pm 15.0$ & - & - & - & - \\
WW (g) & 257 & 7.1 & 217.8 & $78.4 \pm 46.2 \mathrm{~b}$ & 165 & 3.9 & 132.3 & $46.6 \pm 26.8 \mathrm{a}$ \\
\hline
\end{tabular}

${ }^{*}$ Means of the same biometric variable followed by a distinct letter differed statistically $(P<0.05)$

Table 3. Ucides cordatus (Linnaeus, 1763). Results of a regression of each biometric variable, including carapace (CW, width; CC, length), the length of the propodus of the major cheliped (PL, for males), the width of the $5^{\text {th }}$ somite of the abdomen (AW, for females) and the wet weight (WW), with sex and developmental phase (juvenile and adult) and its growth allometric level (AL), represented by: 0 (isometry), + (allometric positive), and - (allometric negative). AF represents adult females, AM represents adult males, JF represents juvenile females, JM represents juvenile males, $\mathrm{n}$ is the number of individuals, TF is the total number of females, TM is the total number of males, and $\mathrm{R}^{2}$ is the coefficient of determination.

\begin{tabular}{|c|c|c|c|c|c|c|c|}
\hline $\begin{array}{l}\text { Biometric } \\
\text { Relationship }\end{array}$ & Sex & $\mathrm{n}$ & $\begin{array}{c}\text { Power Function } \\
y=a x b\end{array}$ & $\begin{array}{l}\text { Linearized Function } \\
\ln \mathrm{y}=\ln \mathrm{a}+\mathrm{b} \ln \mathrm{x}\end{array}$ & $\mathrm{R}^{2}$ & $t$ test & $\mathrm{AL}$ \\
\hline \multirow{6}{*}{ CL x CW } & JM & 125 & $\mathrm{CL}=0.958 \mathrm{CW}^{0.938}$ & $\ln C L=-0.043+0.938 \ln C W$ & 0.92 & $0.73^{\mathrm{ns}}$ & 0 \\
\hline & $\mathrm{AM}$ & 132 & $\mathrm{CL}=1.307 \mathrm{CW}^{0.8601}$ & $\ln C L=0.268+0.8601 \ln C W$ & 0.72 & $3.62 *$ & - \\
\hline & TM & 257 & $\mathrm{CL}=1.041 \mathrm{CW}^{0.916}$ & $\ln \mathrm{CL}=0.0402+0.916 \ln \mathrm{CW}$ & 0.95 & $6.55^{*}$ & - \\
\hline & $\mathrm{JF}$ & 155 & $\mathrm{CL}=1.097 \mathrm{CW}^{0.9062}$ & $\ln C L=0.0926+0.9062 \ln C W$ & 0.93 & $4.36^{*}$ & - \\
\hline & $\mathrm{AF}$ & 7 & $\mathrm{CL}=0.521 \mathrm{CW}^{1.089}$ & $\ln C L=-0.652+1.089 \ln C W$ & 0.50 & $0.28^{\text {ns }}$ & 0 \\
\hline & $\mathrm{TF}$ & 162 & $\mathrm{CL}=1.083 \mathrm{CW}^{0.9096}$ & $\ln \mathrm{CL}=0.0796+0.9096 \ln \mathrm{CW}$ & 0.94 & $4.79^{*}$ & - \\
\hline \multirow{3}{*}{$\mathrm{AW} \times \mathrm{CW}$} & $\mathrm{JF}$ & 75 & $\mathrm{AW}=0.157 \mathrm{CW}^{1.36}$ & $\ln \mathrm{AW}=-1.85+1.36 \ln \mathrm{CW}$ & 0.87 & $5.71 *$ & + \\
\hline & $\mathrm{AF}$ & 82 & $\mathrm{AW}=0.749 \mathrm{CW}^{0.945}$ & $\ln \mathrm{AW}=-0.288+0.945 \ln \mathrm{CW}$ & 0.74 & $0.89^{\text {ns }}$ & 0 \\
\hline & $\mathrm{TF}$ & 157 & $\mathrm{AW}=0.264 \mathrm{CW}^{1.21}$ & $\ln \mathrm{AW}=-1.33+1.21 \ln \mathrm{CW}$ & 0.93 & $7.85^{*}$ & + \\
\hline \multirow{3}{*}{ PL x CW } & $\mathrm{JM}$ & 31 & $\mathrm{PL}=0.5102 \mathrm{CW}^{1.12}$ & $\ln P L=-0.673+1.12 \ln C W$ & 0.79 & $1.12^{\mathrm{ns}}$ & 0 \\
\hline & $\mathrm{AM}$ & 109 & $\mathrm{PL}=0.189 \mathrm{CW}^{1.39}$ & $\ln \mathrm{PL}=-1.67+1.39 \ln \mathrm{CW}$ & 0.96 & $13.20^{*}$ & + \\
\hline & TM & 140 & $\mathrm{PL}=0.261 \mathrm{CW}^{1.31}$ & $\ln \mathrm{PL}=-1.34+1.31 \ln \mathrm{CW}$ & 0.98 & $17.64 *$ & + \\
\hline \multirow{2}{*}{ WW x CW } & TM & 253 & $\mathrm{WW}=0.00050014 \mathrm{CW}^{2.99}$ & $\ln W W=-7.601+2.99 \ln C W$ & 0.97 & $0.28^{\text {ns }}$ & 0 \\
\hline & $\mathrm{TF}$ & 162 & $\mathrm{WW}=0.000469 \mathrm{CW}^{3.00}$ & In WW $=-7.66+3.00$ In CW & 0.96 & $0.0031^{\mathrm{ns}}$ & 0 \\
\hline
\end{tabular}

ns $P>0.05 ;{ }^{*} P<0.05$

\section{Discussion}

The sex ratio indicates that there is an overall predominance of male Ucides cordatus, with an increase in the proportion of this gender during the reproductive period and a decrease during the fattening (non-reproductive period). Castro et al. (2008) reports a dramatically different $U$. cordatus sex ratio (4.9:1) and suggests that sex ratio may vary with the severity of overfishing, the biological season (e.g., molting or reproduction) and/or food availability and abundance. Therefore, sex ratio data must always be carefully evaluated; the number of $U$. cordatus males (i.e., four times higher than that of females) certainly cannot be explained by differential fishery activity because only $U$. cordatus males are fishing targets in northern and northeast Brazilian regions (Capistrano and Lopes, 2012). Indeed, a review of the overall sex ratio of 'uçá-crabs reveals discordant patterns, including: 1) a predominance of males reported by Wunderlich and Pinheiro (2013) in Iguape (São Paulo), 2) a predominance of females reported by Góes et al. (2010) at Vitória Bay (Espírito Santo), and 3) a gender balance reported by Araújo and Calado (2008) in the Estuarine Lagoon Complex of MundaúManguaba at Maceió (Alagoas). Wunderlich and Pinheiro (2013) conduct studies in a pristine and underexplored mangrove area finding a sex ratio dependence of the arboreal composition and tidal flooding level. Therefore, it is strongly 


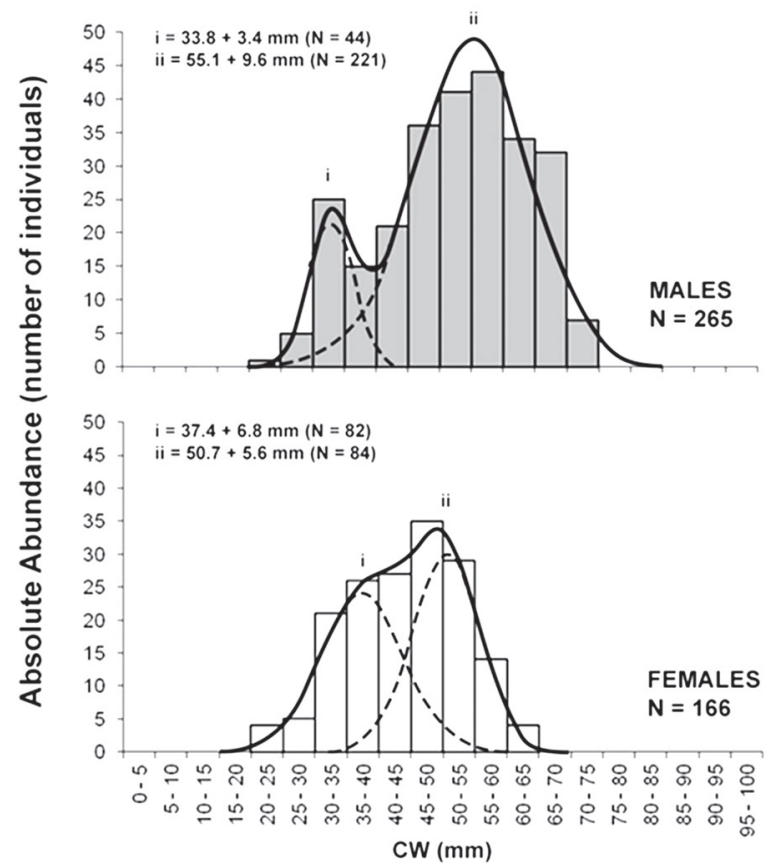

Figure 2. Ucides cordatus (Linnaeus, 1763). The absolute abundance of each sex by size class (CW) captured in the mangroves of the Joanes River, Lauro de Freitas Municipality (Bahia State, Brazil) between September 2011 and August 2012. Normal curves are shown by dashed lines (i and ii) and represent the normal components in each sex (mean \pm standard deviation), and the continuous curve represents their average. $\mathrm{N}$ is the number of individuals and CW is carapace width.



Figure 3. Ucides cordatus (Linnaeus, 1763). The relative frequencies of females (ovigerous and non-ovigerous) captured monthly in the mangroves of the Joanes River, Lauro de Freitas Municipality (Bahia State, Brazil) between September 2011 and August 2012. In December and January, the crab-catchers were not available.

recommended the use of sex ratio compared with phytosociological data of the studied mangrove area to avoid a misinterpretation.

The population structure reveals that both amplitude and normal components (modes) are similar between the sexes. These findings can

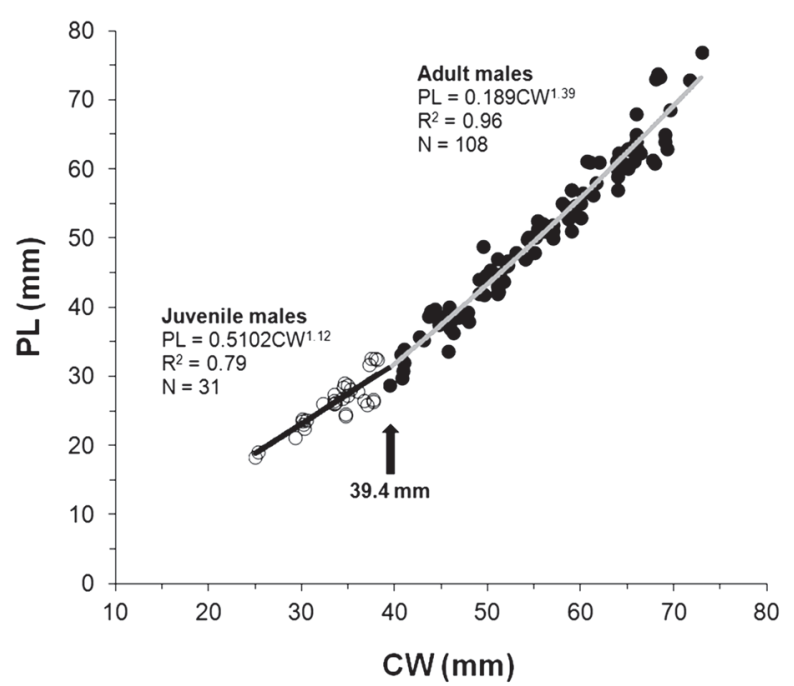

Figure 4. Ucides cordatus (Linnaeus, 1763). Scatter plot of the CLxCW relationship, based on male crabs captured monthly in the mangroves of the Joanes River, Lauro de Freitas Municipality (BA, Brazil) between September 2011 and August 2012. The arrow indicates the size at morphological maturity, PL is the propodus of the major cheliped, $\mathrm{CW}$ is the carapace width, $\mathrm{N}$ is the number of individuals, and $\mathrm{R}^{2}$ is the coefficient of determination.

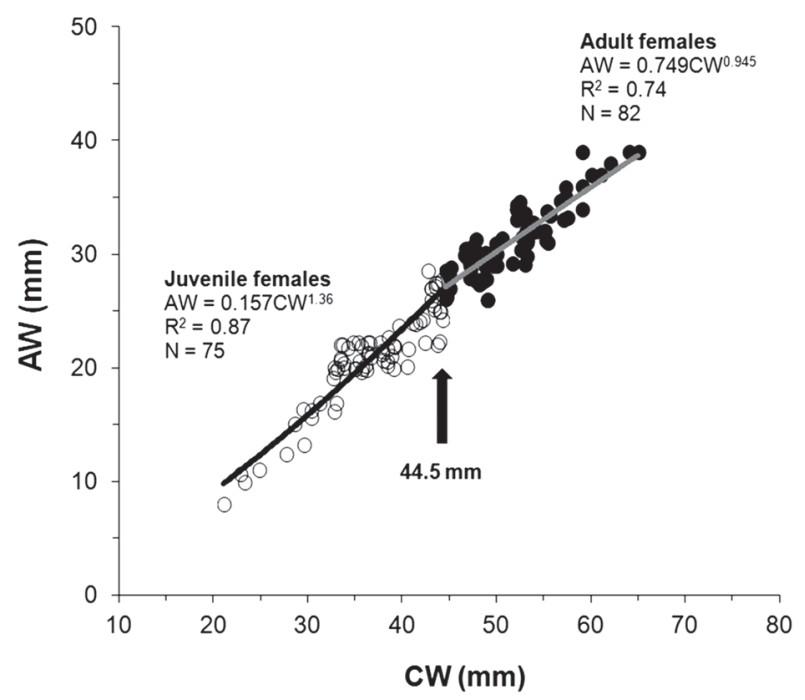

Figure 5. Ucides cordatus (Linnaeus, 1763). Scatter plot of the $\mathrm{AWxCW}$ relationship, based on female crabs captured monthly in the mangroves of the Joanes River, Lauro de Freitas Municipality (Bahia State, Brazil) between September 2011 and August 2012. The arrow indicates the size at morphological maturity, AW is the width of the $5^{\text {th }}$ abdominal somite, CW is the carapace width, $\mathrm{N}$ is the number of individuals, and $\mathrm{R}^{2}$ is the coefficient of determination.

be explained by the slower $U$. cordatus growth constant of the Von Bertalanffy model $(k)$, which ranges from 0.26 (in females) to 0.28 (in males) in Southeast Brazil (Pinheiro et al., 2005 ) and 0.25 (in females) to 0.17 (in males) in Northeast Brazil (Diele and Koch, 2010). The mean sizes $(\mathrm{CW})$ of this species in Iguape 
(São Paulo) were $51.8 \mathrm{~mm}$ (males) and $47.0 \mathrm{~mm}$ (females), which were very close to the values obtained in this study (i.e., 55.4 and $44.5 \mathrm{~mm}$, respectively). However, a comparison of the biometric data of this species does not show a national or regional morphometric pattern (Moura and Coelho, 2004; Lima and Oshiro, 2006). It is possible to speculate that $U$. cordatus can be a resilient mangrove species, because there was not an evident effect in his population structure, despite the human impacts confirmed in Joanes River estuary (e.g., real state pressure, sewage spills and waste) (Sousa, 2014).

Studies on the relative growth of crustaceans (Hartnoll, 1974; 1978; 1982) indicate some patterns using biometric relationships, with ontogenetic changes and relevant reproductive information based on secondary sexual characters. In brachyurans, the CLxCW relationship generally indicates an isometric growth without an expressive growth rate difference over ontogeny (Pinheiro and Fransozo, 1993). However, Pinheiro and Hattori (2006) reported a reduction of the $\mathrm{CW}$ growth rate in $U$. cordatus males during puberal molt (juvenile to adult phase); an opposite pattern was reported for females. Therefore, these authors verified that $\mathrm{CLxCW}$ relationship could be successfully used to indicate the CW morphologic maturity for this species that were similar between sexes (males: $59.1 \mathrm{~mm}$; and females: $58.2 \mathrm{~mm}$ ). These values were nearest to those obtained in this study (53.7 and 58.0 $\mathrm{mm}$, respectively). It is possible that these puberty size greatly influences the life cycle of $U$. cordatus and possibly coincides with an increase of the gill chamber volume, an adaptation for air storage in the semi-terrestrial crabs (Greenaway, 1984a; 1984b). This size difference can also be used to promote sex recognition, a fact previously suggested for this species by Pinheiro and Fiscarelli (2001).

Chela size in males can be used to reveal the maturity size. As in other crabs the chela size in adult males of $U$. cordatus is a secondary sexual character associated with the agonistic interaction (competition) among male individuals, and other reproductive behaviour related to courtship, handling of females, and other functions (Pinheiro and Fransozo, 1999; Nordhaus et al., 2009; Castiglioni and Coelho, 2011; Sampaio et al., 2011). The PLxCW relationship indicates that the chela size of males grows more quickly than its body $(\mathrm{CW})$ after the puberal molt, verified from
39.4 CW $\mathrm{mm}$ in this study. The puberty size that was reported in this study was very similar to the size range (37.3 and $38.0 \mathrm{~mm} \mathrm{CW}$ ) registered by Castiglioni and Coelho (2011) to this same species in pristine mangroves of Tamandaré (Pernambuco, Brazil). These sizes are smaller than those indicated in a review by Ibama (2011), with a size at maturity for $U$. cordatus males ranging between 44 to $61 \mathrm{CW} \mathrm{mm}$. These results confirm maturity sizes generally larger at lower latitudes, confirming the review presented by Ibama (2011).

It is necessary to note that mangroves at Joanes River are located in an Environmental Protected Area (Joanes-Ipitanga EPA). Nevertheless, many anthropic pressures were detected in this place, represented by diffuse pollution sources (e.g., organic wastewater, chemical residues from marinas, etc.) that can threaten the mangrove ecosystem. Considering this reduced environmental quality, these pollution sources could affect the population biology and reproduction of the mangrove biota in these areas (Andrade et al., 2007). Although an evident higher degree of pollution in the mangrove ecosystem of the Joanes River estuary than in the pristine mangroves studied by Castiglioni and Coelho (2011), a similar maturity size was registered among these areas. This finding suggests that $U$. cordatus is highly resilient in mangrove areas with different degrees of environmental quality.

Abdominal morphometry in brachyuran females changes over the life cycle, and most changes are detected between developmental phases (juvenile and adult) (Hartnoll, 1974; 1982; Pinheiro and Fransozo, 1998). In portunid crabs, a clear overlap between these phases is evident, but this observation is not confirmed for all brachyuran families. Ucides cordatus females follow this latter biometric pattern, in which the abdominal width (AW) grows in positive allometry with body size $(\mathrm{CW})$ in the juvenile phase and becomes isometric in the adult phase to maximize egg protection and incubation (Maciel and Alves, 2009; Mendonça and Pereira, 2009; Oliveira et al., 2013). In the Joanes-Ipitanga EPA, female morphological puberty $(44.5 \mathrm{~mm} \mathrm{CW})$ was within the range of the $U$. cordatus female maturity sizes reported in Brazil (46.7 \pm 5.7 mm CW) (Ibama, 2011).

In Tab. 4, the percent of each developmental phase (juvenile or adult) is presented as a function of sex and size at maturity size for each biometric 
Table 4. Ucides cordatus (Linnaeus, 1763). Number of individuals (percent within parentheses) in each developmental phase (juvenile and adult) and maturity size estimated by the biometric relationships in comparison with minimum capture size by Brazilian laws. AW represents the abdominal width of $5^{\text {th }}$ somite, CW is the carapace width, and PL is the propodus length of major chela.

\begin{tabular}{|c|c|c|c|c|c|}
\hline Sex & $\mathrm{N}$ & Biometric relationships or Brazilian Law & $\mathrm{CW}(\mathrm{mm})$ & Juveniles & Adults \\
\hline & & PLxCW & 39.4 & $47(17.7)$ & $218(82.3)$ \\
\hline \multirow[t]{3}{*}{ Male } & 265 & CLxCW & 53.7 & $132(49.8)$ & $133(50.2)$ \\
\hline & & Ibama (2003a; 2003b)* & 60.0 & $184(69.4)$ & $81(30.6)$ \\
\hline & & AWxCW & 44.5 & $78(47.0)$ & $88(53.0)$ \\
\hline \multirow[t]{3}{*}{ Female } & 166 & CLxCW & 58.0 & 157 (94.6) & $9(5.4)$ \\
\hline & & Ibama (2003a; 2003b) & 60.0 & $160(96.4)$ & $6(3.6)$ \\
\hline & & PLxCW and AWxCW & & $125(29.0)$ & $306(71.0)$ \\
\hline \multirow[t]{2}{*}{ Total } & 431 & CLxCW & & $289(67.1)$ & $142(32.9)$ \\
\hline & & Ibama (2003a; 2003b) & & $344(79.8)$ & $87(20.2)$ \\
\hline
\end{tabular}

* Brazilian laws \#52/2003 (North-Northeast Region) and \# 53/2003 (South-Southeast Region).

relationship (i.e., carapace, chelae and abdomen) and compared to the minimum capture size defined by Brazilian law (Ibama, 2003a; 2003b). A less conservative (but reliable) estimate of size at maturity may be obtained by using the sizes of the chelae (males) and the abdomen (females) instead of the sizes specified by Brazilian laws or by carapace relationships (CLxCW).

The relationship of WWxCW in $U$. cordatus indicates that there is an isometric growth rate for both sexes. This finding is in agreement with male data obtained by Pinheiro and Fiscarelli (2009) at Iguape (São Paulo, Brazil), but it contrasts with the negative allometry detected for females by these authors. It is possible that this slight weight reduction in females could be explained by differential degrees of repletion and gonadal maturation, as suggested by Araújo and Calado (2008) for crabs from the MundaúManguaba Estuarine Lagoon Complex (Alagoas, Brazil). This regional difference illustrates the intrinsic relationship between biological processes in this species (e.g., growth and reproduction) and environmental factors, sex, and gonadal maturation (Pinheiro and Fiscarelli, 2009). The life cycle of $U$. cordatus is dramatically influenced by changes in temperature, rainfall and tidal amplitude; these factors determine the initiation (and time modulation) of some reproductive events (e.g., nuptial molt, mating, gonadal maturation and spawning) (Sant'Anna et al., 2014) and other biological events, such as the $U$. cordatus fattening period during the winter months.

The reproductive period in brachyuran crabs can be defined as the months with highest number of adult females ( $\mathrm{CW}>$ maturity size), considering those with mature gonads and/or eggs (Castiglioni et al., 2011; Castilho-Westphal et al., 2013). In the present study, ovigerous females were only found during three months (March to May), due to absence of two sampling months (December and January), which corresponds to the minimum $U$. cordatus spawning period (ranging from 3 to 5 months) that was reported in a recent review (Ibama, 2011). However, Pinheiro and Fransozo (2002) suggest that the reproductive season in decapod crustaceans needs to be evaluated more extensively by categorizing reproduction as continuous, seasonal or seasonal-continuous. A more complete analysis of the reproductive biology of $U$. cordatus in Brazil revealed this species' seasonal reproduction, with a complete absence of females with mature gonads and/or ovigerous females during some months of year (Pinheiro and Fiscarelli, 2001; Ibama, 2011). According to Castiglioni et al. (2013), this species showed a higher breeding activity in the spring and summer months in the state of Pernambuco (Brazil), where a large number of mature individuals could be found. Therefore, the reproductive period of $U$. cordatus varies with geographic latitude (Pinheiro and Fiscarelli, 2001; Sampaio et al., 2011). A review on this subject in Brazil (Ibama, 2011) reveals that five months (December to April) represent the maximum length of the reproductive season, based on ovigerous females in the northern region, and that a reproductive delay occurs in the northeast region (generally from January to May). Nevertheless, in some regions, there is a shorter reproductive season of three months, as reported by Oliveira et al. (2013) for crabs from Ariquindá and Mamucabas (Pernambuco, Brazil). In 
addition, Souto $(2007,2008)$ identified an eightmonth (March to October) fattening season (i.e., the period without ovigerous females) in Acupe (Bahia, Brazil).

Despite the high habitat fragmentation and anthropic pressures in the mangrove ecosystem of the Joanes River, the population parameters and reproduction of $U$. cordatus were similar to those of more preserved mangrove ecosystems. This finding suggests that $U$. cordatus is a mangrove species with great resilience to poor environmental quality, supported by the fact that in the Joanes estuary there was a large number of ovigerous females and juveniles.

\section{Conclusions}

The estimated size (i.e., carapace width, CW) at morphological maturity for Ucides cordatus in the Joanes River mangrove ecosystem was 39.4 $\mathrm{mm}$ (for males) and $44.5 \mathrm{~mm}$ (for females). These sizes corresponded to $82.3 \%$ of all males and $52.0 \%$ of all females. These estimates are less conservative than the maturity sizes specified by Brazilian law for this fishery resource (which represent $30.6 \%$ and $3.6 \%$ of all males and females, respectively).

The mangrove ecosystem of the Joanes estuary is reduced, fragmented and subject to many anthropic pressures. Nevertheless, this study does not indicate a reduction in the population or reproductive parameters of $U$. cordatus; instead, these parameters are similar to those of more preserved mangrove ecosystems. This finding indicates that this crustacean is a resilient species with respect to environmental quality.

\section{ACKNOWLEDgments}

We thank Mr. Leopoldo S. Moraes for providing the financial support for this research and the Fishery Association of Buraquinho, represented by Mr. Jonas T. dos Santos, and the four fishermen (Adilson, Djalma, Marcos and 'Seu' Jorge) for their assistance during field expeditions and for facilitating the capture of the specimens. We are also very grateful to Gustavo H. S. Pinheiro for helping with the final design of the figures and to Elsevier Webshop for the English language editing of this manuscript. MAAP is grateful to CNPq for a scientific research fellowship with which to conduct this study.

\section{REFERENCES}

Adams, A.J.; Dahlgren, C.P.; Kellison, G.T.; Kendall, M.S.; Layman, C.A.; Ley, J.A.; Nagelkerken, I. and Serafy, J.E. 2006. Nursery function of tropical back-reef systems. Marine Ecology Progress Series, 318: 287-301.

Alvares, C.A.; Stape, J.L.; Sentelhas, P.C.; Gonçalvez, J.L.M. and Sparovek, G. 2013. Köppen's climate classification map for Brazil. Meteorologische Zeitschrift, 22(6): 711-728.

Alves, M.I.M. 1975. Sobre a reprodução do caranguejo-uçá, Ucides cordatus (Linnaeus) em mangues do estado de Ceará (Brasil). Arquivo Ciências do Mar, 15(2): 85-91.

Alves, R.R.N. and Nishida, A.K. 2004. Population structure of the mangrove crab Ucides cordatus (Crustacea: Decapoda: Brachyura) in the Estuary of the Mamanguape River, Northeast Brazil. Tropical Oceanography, 32(1): 23-37.

Andrade, C.E.; Vasconcelos, J.A.; Oliveira, S.M. and Ivo, C.T.C. 2007. Biologia e pesca do caranguejo-uçá, Ucides cordatus (Linnaeus, 1763), no estuário do rio Curimatau, município de Canguaretama - Rio Grande do Norte. Boletim Técnico Científico do CEPENE, 15(1): 31-41.

Araújo, M.S.L.C. and Calado, T.C.S. 2008. Bioecologia do caranguejo-uçá Ucides cordatus (Linnaeus) no Complexo Estuarino Lagunar Mundáu/Manguaba (CELMM), Alagoas, Brasil. Revista da Gestäo Costeira Integrada, 8(2): 169-181.

Araújo, M.S.L.C.; Castiglioni, D.S. and Coelho, P.A. 2012. Width-weight relationship and condition factor of Ucides cordatus (Crustacea, Decapoda, Ucididae) at tropical mangroves of Northeast Brazil. Iheringia, Série Zoologia, 102(3): 277-284.

Barboza, D.C.P.M.; Gomes-Neto, C.M.B.; Leal，D.C.; Bittencourt, D.V.V.; Carneiro, A.J.B.; Souza, B.M.P; Oliveira, L.S.; Juliāo, F.S.; Souza, V.M.M. and Franke, C.R. 2006. Estudo de coorte em áreas de risco para leishmaniose visceral canina, em municípios da Região Metropolitana de Salvador, Bahia, Brasil. Revista Brasileira de Saúde e Produção Animal, 7(2): 152-163.

Bernini, E.; Silva, M.A.B.; Carmo, T.M.S. and Cuzzuol, G.R. 2006. Composição química do sedimento e de folhas das espécies de manguezal do estuário de São Mateus, Espírito Santo, Brasil. Revista Brasileira de Botânica, 29(4): 689-699.

Capistrano, J.F. and Lopes, P.F.M. 2012. Crab gatherers perceive concrete changes in the life history traits of Ucides cordatus (Linnaeus, 1763), but overestimate their past and current catches. Ethnobiology and Conservation, 1: 1-21.

Castiglioni, D.S. and Coelho, A.P. 2011. Determinaçẫo da maturidade sexual de Ucides cordatus (Crustacea, Brachyura, Ucididae) em duas áreas de manguezal do litoral sul de Pernambuco, Brasil. Iheringia, Série Zoologia, 101(1-2): 138-144.

Castiglioni, D.S.; Silva, J.V.C.L. and Azevedo, D.S. 2011. Relative growth and its use to determine the morphological sexual maturity of Ucides cordatus (Linnaeus, 1763) (Decapoda, Brachyura, Ucididae) from two mangrove areas on the northeastern Brazilian coast. Crustaceana, 84(10): 1221-1241. 
Castiglioni, D.S.; Silva-Castiglioni, D. and Oliveira, P.J.A. 2013. Biologia reprodutiva de Ucides cordatus (Linnaeus, 1763) (Crustacea, Brachyura, Ucididae) em duas áreas de manguezal do litoral sul do Estado de Pernambuco, Brasil. Revista da Gestão Costeira Integrada, 13(4): 433444.

Castilho-Westphal, G.G.; Ostrensky, A.; Pie, M.R. and Boeger, W.A. 2013. Morphology of the female reproductive system and reproductive cycle of the mangrove land crab Ucides cordatus (L.) in the Baía de Antonina, Paraná, Brazil. Acta Zoologica, 94: 86-93.

Castro, A.C.L.; Correia, M.L.F.; Nascimento, A.R.; PiedadeJúnior, R.N.; Gama, L.R.M.; Sousa, M.M.; Sena, A.C.S. and Sousa, R.C.C. 2008. Aspectos bioecológicos do caranguejo-uçá (Ucides cordatus cordatus L., 1763) (Decapoda, Brachyura) nos manguezais da ilha de São Luís e litoral oriental do Estado do Maranhão, Brasil. Amazônia: Ciência \& Desenvolvimento, 3(6): 17-36.

Cetrel. 2011. Campanha de Amostragem de Água Superficial - Rio Joanes/Ponte da Estrada do Côco. Available at http://riolimpo.org.br/wp-content/uploads/2011/05/ Relatrio_Rio_Joanes-Final_1.pdf Accessed on 03 April 2015.

Christofoletti, R.A.; Hattori, G.Y. and Pinheiro, M.A.A. 2013. Food selection by a mangrove crab: temporal changes in fasted animals. Hydrobiologia, 702: 63-72

Dalabona, G. and Silva, J.L. 2005. Período reprodutivo de Ucides cordatus (Linnaeus) (Brachyura, Ocypodidae) na Baía das Laranjeiras, sul do Brasil. Acta Biologica Paranaense, 34(1-4): 115-126.

Diele, K. and Koch, V. 2010. Growth and mortality of the exploited mangrove crab Ucides cordatus (Ucididae) in N-Brazil. Journal of Experimental Marine Biology and Ecology, 395(1-2): 171-180.

Gayanilo-Jr, F.C.; Sparre, P. and Pauly, D. 1996. FAOICLARM Stock Assessment Tools. User's Manual. Computerized Information Series - Fisheries, Rome. 23p.

Góes, P.; Branco, J.O.; Pinheiro, M.A.A.; Barbieri, E.; Costa, D. and Fernandes, L.L. 2010. Bioecology of the uçá-crab, Ucides cordatus (Linnaeus, 1763), in Vitória bay, Espírito Santo State, Brazil. Brazilian Journal of Oceanography, 58(2):153-163.

Greenaway, P. 1984a. Survival strategies in desert crabs. p. 145-152. In: H.G. Cogger and E. Cameron (ed), Arid Australia. Sidney, Australian Museum.

Greenaway, P. 1984b.The relative importance of the gills and lungs in the gas exchange of amphibious crabs of the genus Holthuisana. Australian Journal of Zoology, 32: 1-6.

Hartnoll, R.G. 1974. Variation in growth pattern between some secondary sexual characters in crabs (Decapoda, Brachyura). Crustaceana, 27(2): 131-136.

Hartnoll, R.G. 1978. The determination of relative growth in Crustacea. Crustaceana, 34(3): 281-293.

Hartnoll, R.G. 1982. Growth. p.111-196. In: L.G. Abele (ed), The Biology of Crustacea, Vol. 2. Embriology, Morphology and Genetics. New York, Academic Press.
Hattori, G.Y. and Pinheiro, M.A.A. 2003. Fertilidade do caranguejo de mangue Ucides cordatus (Linnaeus) (Crustacea, Brachyura, Ocypodidae) em Iguape, São Paulo, Brasil. Revista Brasileira de Zoologia, 20(2): 309-313.

Huxley, J.S. 1950. Relative growth and form transformation. Proceedings of Royal Society of London, 137: 465-469.

Ibama. 2003a. Instituto Brasileiro do Meio Ambiente e dos Recursos Renováveis. Portaria no 034/03-N, de 24 de junho de 2003. Defeso pesqueiro do caranguejo-uçá (Ucides cordatus), nas regiōes norte-nordeste do Brasil.

Ibama. 2003b. Instituto Brasileiro do Meio Ambiente e dos Recursos Renováveis. Portaria no 52/03, de 30 de setembro de 2003. Defeso pesqueiro do caranguejo-uçá (Ucides cordatus), nas regiôes sudeste-sul do Brasil.

Ibama. 2004. Instituto Brasileiro do Meio Ambiente e dos Recursos Renováveis. Instrução Normativa Interministerial do Ministério do Meio Ambiente (MMA) no 05/2004, de 21 de maio de 2004. Reconhece como espécies ameaçadas de extinção e espécies sobreexplotadas ou ameaçadas de sobreexplotação, os invertebrados aquáticos e peixes, constantes dos Anexos à Instrução Normativa, Brasília, DF. Diário Oficial da União, 102: 136-142.

Ibama, 2011. Instituto Brasileiro do Meio Ambiente e dos Recursos Renováveis. Proposta de Plano Nacional para o uso sustentável do caranguejo-uçá, guaiamum e do siriazul. Dias-Neto, J. (org.) - Brasília. 156p.

Ihaka, R. and Gentleman, R. 1996. R: A language for data analysis and graphics. Journal of Computational and Graphical Statistics, 5(3): 299-314.

Legendre, P. and Legendre L. 1998. Numerical Ecology. $2^{\text {nd }}$ Edition. San Francisco, Elsevier, 853p.

Leite, N.R.; Pereira L.C.C. and Costa, R.M. 2009. Distribuição temporal do mesozooplâncton no furo Muriá, Pará, Brasil. Boletim do Museu Paraense Emílio Goeldi Ciências Naturais, 4(2): 149-164.

Lima, C.O. and Oliveira, R.C. 2011. Análise Ambiental de Ocupação nas Áreas de Manguezais no Município de Santos-SP. Revista Geográfica de América Central, Número Especial EGAL, Costa Rica, Vol. 2, n 47 e.

Lima, G.V. and Oshiro, L.M.Y. 2006. Maturidade sexual do caranguejo Armases rubripes (Rathbun) (Crustacea, Brachyura, Sesarmidae) da Baía de Sepetiba, Rio de Janeiro, Brasil. Revista Brasileira de Zoologia, 23(4): 1087-1086.

Maciel, D.C. and Alves, A.G.C. 2009. Conhecimentos e práticas locais relacionados ao aratu Goniopsis cruentata (Latreille, 1803) em Barra de Sirinhaém, litoral sul de Pernambuco, Brasil. Biota Neotropica, 9(4): 29-36.

Masunari, S. and Swiech-Ayoub, B.P. 2003. Crescimento relativo em Uca leptodactyla Rathbun (Crustacea, Decapoda, Ocypodidae). Revista Brasileira de Zoologia, 20(3): 487-491.

Mendonça, J.T. and Pereira, A.L.C. 2009. Avaliação das capturas de caranguejo-uçá Ucides cordatus no município de Iguape, litoral sul de São Paulo, Brasil. Boletim Técnico do Instituto de Pesca, 35(2): 169-179. 
MMA. 2014. Ministério do Meio Ambiente. Portaria $n^{\circ}$ 445/2014, de 18 de dezembro de 2014. Lista Nacional Oficial de Espécies da Fauna Ameaçadas de Extinção - Peixes e Invertebrados Aquáticos. Diário Oficial da União, 256: 126-130.

Moreau, A.M.S.S.; Hora, J.B.; Amorim, R.R.; Ker, J.C.; Gomes, F.G. and Moreau, S.M. 2010. Uso e ocupação de manguezais da área urbana de Ilhéus: uma abordagem histórica e socioambiental. Revista de Gestão Costeira Integrada, 10(1): 1-8.

Moura, M.A.L. and Querino, C.A.S. 2010. Variação sazonal do fluxo de calor no solo dentro de um manguezal tropical. Revista Brasileira de Engenharia Agrícola $e$ Ambiental, 14(3): 296-302.

Moura, N.F.O. and Coelho, P.A. 2004. Maturidade sexual fisiológica em Goniopsis cruentata (Latreille) (Crustacea, Brachyura, Grapsidae) no Estuário do Paripe, Pernambuco, Brasil. Revista Brasileira de Zoologia, 21(4): 1011-1015.

Ng, P.K.L.; Guinot D. and Davie, P.J.F. 2008. Systema Brachyurorum. Part I. An annotated checklist of extant brachyuran crabs of the world. Raffles Bulletin of Zoology, 17: 1-286.

Nicolau, C.F. and Oshiro, L.M.Y. 2007. Distribuição espacial, sazonal e estrutural do caranguejo Aratus pisonii (H. Milne Edwards) (Crustacea, Decapoda, Sesarmidae) do manguezal de Itacuruçá, Rio de Janeiro, Brasil. Revista Brasileira de Zoologia, 24(2): 463-469.

Nordhaus, I.; Diele, K. and Wolff, M. 2009. Activity patterns, feeding and burrows behaviour of the crab Ucides cordatus (Ucididae) in a high intertidal mangrove forest in North Brazil. Journal of Experimental Marine Biology and Ecology, 374(2): 104-112.

Oliveira, P.J.A.; Coelho, P.A. and Castiglioni, D.S. 2013. Population biology of Ucides cordatus (Linnaeus, 1763) (Crustacea, Brachyura, Ucididae) from two tropical mangroves sites in northeast coast of Brazil. PanAmerican Journal of Aquatic Sciences, 8(2): 89-103.

Pinheiro, M.A.A. and Fiscarelli, A.G. 2001. Manual de Apoio à Fiscalização do Caranguejo-Uçá (Ucides cordatus). 1a Edição. Itajaí, Instituto Brasileiro do Meio Ambiente (IBAMA)/Centro de Pesquisa e Gestão de Recursos Pesqueiros do Litoral Sudeste e Sul (CEPSUL), 43p.

Pinheiro, M.A.A. and Fiscarelli, A.G. 2009. Length-weight relationship of the carapace and condition factor of the mangrove crab Ucides cordatus (Linnaeus, 1763) (Crustacea, Brachyura, Ucididae). Brazilian Archives of Biology and Technology, 52(2): 397-406.

Pinheiro, M.A.A.; Fiscarelli, A.G. and Hattori, G.Y. 2005. Growth of the mangrove crab Ucides cordatus (Brachyura, Ocypodidae). Journal of Crustacean Biology, 25(2): 293301.

Pinheiro, M.A.A. and Fransozo, A. 1993. Relative growth of the speckled swimming crab Arenaeus cribrarius (Lamarck, 1818) (Crustacea, Brachyura, Portunidae), in Ubatuba Coast, São Paulo, Brazil. Crustaceana, 65(3): 377-389.
Pinheiro, M. A. A. and Fransozo, A. 1998. Sexual maturity of speckled swimming crab Arenaeus cribrarius (Lamarck, 1818) (Decapoda: Brachyura: Portunidae), in Ubatuba littoral, São Paulo State, Brazil. Crustaceana, 71: 434452.

Pinheiro, M.A.A. and Fransozo, A. 1999. Reproductive behavior of the swimming crab Arenaeus cribrarius (Lamarck, 1818) (Crustacea, Brachyura, Portunidae) in captivity. Bulletin of Marine Science, 64(2): 243253.

Pinheiro, M.A.A. and Fransozo, A. 2002. Reproduction of the speckled swimming crab Arenaeus cribrarius (Lamarck, 1818) (Brachyura, Portunidae) on the Brazilian Coast near 2330'S. Journal of Crustacean Biology, 22(2): 416-428.

Pinheiro, M.A.A. and Hattori, G.Y. 2006. Relative growth of the mangrove crab Ucides cordatus (Linnaeus, 1763) (Crustacea, Brachyura, Ocypodidae) at Iguape, São Paulo, Brazil. Brazilian Archives of Biology and Technology, 49(5): 813-823.

Pinheiro, M.A.A.; Silva, P.P.G.; Duarte, L.F.A.; Almeida, A.A. and Zanotto, F.P. 2012. Accumulation of six metals in the mangrove crab Ucides cordatus (Crustacea: Ucididae) and its food source, the red mangrove Rhizophora mangle (Angiosperma: Rhizophoraceae). Ecotoxicology and Environmental Safety, 81: 114-121.

Reis-Filho, J.A.; Nunes, L.D.C.; Menezes, B.L. and Souza, G.B.G. 2010. Variação espaço-temporal e efeito do ciclo lunar na ictiofauna estuarina: evidências para o estuário do Rio Joanes - Bahia. Biotemas, 23(2): 111-122.

Rodrigues, A.M.T.; Branco, E.J.; Saccardo, S.A. and Blankensteyn, A. 2000. A explotação do caranguejo Ucides cordatus (Decapoda: Ocypodidae) e o processo de gestão participativa para normatização da atividade na região sudeste-sul do Brasil. Boletim do Instituto de Pesca, 26(1): 63-78.

Sampaio, F.D.F.; Carmo, T.M.S.; Ostrensky, A.; Castilho, G. and Zeni, T.O. 2011. Determinação do período reprodutivo e do tamanho de maturação funcional dos ovários de Ucides cordatus (Linnaeus, 1763) (Brachyura, Ocypodidae) na baía de Vitória, Espírito Santo. Archives of Veterinary Science, 16(3): 87-96.

Sant'Anna, B.S.; Borges, R.P.; Hattori, G.Y. and Pinheiro, M.A.A. 2014. Reproduction and management of the mangrove crab Ucides cordatus (Crustacea, Brachyura, Ucididae) at Iguape, São Paulo, Brazil. Anais da Academia Brasileira de Ciências, 86(3): 63-73.

Sastry, A.N. 1983. Ecological aspects of reproduction. p. 179-270. In: F.J. Vernberg and W.B. Vernberg (eds). The Biology of Crustacea, Vol. 8. Environment adaptations. New York, Academic Press.

Sobrinho, M.A.M. and Andrade, A.C. 2009. O desafio da conservação de manguezais em áreas urbanas: identificação e análise de conflitos socioambientais no Manguezal do Pina - Recife - PE - Brasil. Unimontes Cientifica, 11(1/2): 8-16. 
Sokal, R.R. and Rohlf, F.J. 2003. Biometry: The principles and practice of statistics in biological research. $3^{\text {rd }}$ Edition. New York, W.H. Freeman, 887p.

Sousa, G.B. 2014. Percepção ambiental do conselho gestor da APA Joanes-Ipitanga como contribuição para a gestáo de mananciais de abastecimento da região metropolitana de Salvador. XII Simpósio de Recursos Hídricos do Nordeste. Available at http://www.abrh.org.br/xiisrhn/anais/papers/ PAP018183.pdf. Accessed on 03 April 2015.

Souto, F.J.B. 2007. Uma abordagem etnoecológica da pesca do caranguejo, Ucides cordatus Linnaeus, 1763 (Decapoda: Brachyura), no manguezal do Distrito de Acupe (Santo Amaro-BA). Biotemas, 20(1): 69-80.

Souto, F.J.B. 2008. O bosque de mangues e a pesca artesanal no Distrito de Acupe (Santo Amaro, Bahia): Uma abordagem etnoecológica. Acta Scientiarum. Biological Sciences, 30(3): 275-282.
Števčić, Z. 2005. The reclassification of brachyuran crabs (Crustacea: Decapoda: Brachyura). Natura Croatica, 14(1): 1-159.

Tse, P.; Nip, T.H.M. and Wong, C.K. 2008. Nursery function of mangrove: A comparison with mudflat in terms of fish species composition and fish diet. Estuarine, Coastal and Shelf Science, 80: 235-242.

Vasques, R.O.R.; Tonini, W.C.T.; Cuevas, J.M.; Santos, D.F.; Faria, T.A.; Falcâo, F.C.; Simôes, D.R.; Batista, R.L.G. and Couto, E.C.G. 2011. Utilização das áreas de manguezais em Taipús de Dentro (Maraú, Sul da Bahia). Revista da Gestão Costeira Integrada, 11(2): 155-161.

Wunderlich, A.C. and Pinheiro, M.A.A. 2013. Mangrove habitat partitioning by Ucides cordatus (Ucididae): effects of the degree of tidal flooding and tree-species composition during its life cycle. Helgoland Marine Research, 67(2): 279-289. 
